\title{
The Douro estuary (Portugal): a mesotidal salt wedge
}

\author{
Mário E.C. VIEIRA a , Adriano A. BORDALO ${ }^{\text {b* }}$ \\ ${ }^{a}$ Oceanography Department, US Naval Academy, Annapolis, MD 21402-5026, USA \\ ${ }^{\mathrm{b}}$ Institute of Biomedical Sciences, Lg. Abel Salazar, 2, P-4090-003 Porto, Portugal
}

Received 24 November 1999; revised 17 April 2000; accepted 5 May 2000

\begin{abstract}
The Douro River drains a large part of the Iberian Peninsula before it flows into the Atlantic Ocean in northern Portugal. Although heavily dammed throughout its course, the Douro forms a mesotidal estuary in the last $22 \mathrm{~km}$. No data had ever been collected in this estuary prior to 1994. An analysis of salinity data measured once a month in 1994 and current data obtained in the fall of 1994 revealed a salt wedge estuary highly dependent on river discharge: strong vertical salinity stratification under conditions of low runoff, whereas during high river flows the whole estuary became a river. The tide in the fall of 1994 was very close to a standing wave throughout the estuary; the tidal range, as high as $2.8 \mathrm{~m}$ at spring tides, was not powerful enough to destroy the vertical stratification. Tidal straining prevented mixing within the salt wedge during ebb; however, the column became vertically mixed at the end of flood. The salt wedge became arrested at three favored positions determined by the bathymetry. The salt intrusion, more sensitive to freshwater inflow than to tidal action, penetrated as far as $2 / 3$ of the estuary's length. Residence times were estimated with a box model and were dependent on river discharge; they varied from 8 hours with early spring (March) inflows to 16 days under summer runoff conditions. (C) 2000 Ifremer/CNRS/IRD/Éditions scientifiques et médicales Elsevier SAS
\end{abstract}

Résumé - L'estuaire du Douro (Portugal) : coin salé mésotidal. Le Douro est un fleuve dont le bassin versant est le plus important de la Péninsule ibérique car il draine $17 \%$ de son territoire. Avec un débit liquide moyen de $480 \mathrm{~m}^{3} \mathrm{~s}^{-1}$, le Douro se jette dans l'océan Atlantique à Porto. Le long du cours principal du fleuve, long de 930 $\mathrm{km}$, et de ses tributaires, environ soixante grands barrages hydroélectriques contrôlent le flux d'eau douce arrivant à l'estuaire. L'estuaire mésotidal est actuellement confiné aux derniers $22 \mathrm{~km}$. L'analyse des données (i) de salinité, obtenues entre janvier et décembre 1994 en marée de vive eau, et (ii) de courants durant l'automne 1994, a démontré l'existence d'une intrusion saline liée au débit du fleuve. Une situation de faible débit conduit à une stratification verticale prononcée. Quand le débit augmente, l'eau douce domine dans l'estuaire. Durant l'automne 1994, la marée était proche d'une onde stationnaire avec une amplitude de 2,8 mètres. Cependant, elle n'était pas suffisamment puissante pour perturber la stratification verticale de la colonne d'eau. La friction provoquée par le courant est le mécanisme de mélange le plus important, très active en amont de l'intrusion saline. Trois points nodaux principaux d'arrêt des eaux de mer, conditionnés par la bathymétrie, se localisent à 2,6; 7,5 et $15 \mathrm{~km}$ de l'embouchure. L'intrusion saline est donc plus sensible au débit du fleuve qu'à l'action tidale. La pénétration d'eau de mer vers l'amont couvre environ deux tiers de l'estuaire. Le temps de résidence de la masse d'eau dans l'estuaire, estimé a partir d'un modèle de boîtes, dépend fortement du débit du fleuve et se situe entre 8 heures au printemps (fort débit) et 16 jours en été (faible débit). (C) 2000 Ifremer/CNRS/IRD/Éditions scientifiques et médicales Elsevier SAS

\section{Estuarine circulation / salt wedge / box model / residence time / Douro River}

Circulation estuariene / coin salé / modèle en boîte / temps de residence / Douro

\footnotetext{
* Correspondence and reprints:

E-mail address: bordalo@icbas.up.pt (A.A. Bordalo).
} 


\section{INTRODUCTION}

The Douro is one of the longest rivers in the Iberian Peninsula, sharing its $930 \mathrm{~km}$ with Spain and Portugal (figure 1), while the $98000 \mathrm{~km}^{2}$ of its watershed cover about $17 \%$ of the peninsula. It drains into the Atlantic Ocean at $41^{\circ} 08^{\prime} \mathrm{N}$ and $8^{\circ} 42^{\prime} \mathrm{W}$, near Portugal's second largest city of Porto.

The river and its tributaries are heavily dammed for hydroelectric power generation and irrigation. In the last one third of its course the Douro has one large dam about every $30 \mathrm{~km}$. In the Portuguese side of the watershed ( $20 \%$ of the total) the dams built in the last 40 years have a capacity of $1.1 \mathrm{~km}^{3}$, while on the Spanish side their capacity exceeds $7 \mathrm{~km}^{3}$. The mean annual discharge of the Douro at the end of its course was $421 \mathrm{~m}^{3} \mathrm{~s}^{-1}$ between 1985 and 1994. In June of 1985 the last dam (Crestuma), located 21.6 $\mathrm{km}$ from the mouth, started operating and the estuary was confined to its present length.

The Douro estuary is a semi-diurnal mesotidal estuary (Davies, 1964); the average spring tidal range is $2.8 \mathrm{~m}$ at the mouth and $2.6 \mathrm{~m}$ at the head. The lower estuary extends $3 \mathrm{~km}$ from the mouth and is $645 \mathrm{~m}$ wide with an average depth of $7.8 \mathrm{~m}$; the middle estuary is $271 \mathrm{~m}$ wide and $10 \mathrm{~m}$ deep and the upper part is $333 \mathrm{~m}$ wide and about $7 \mathrm{~m}$ deep (Bordalo, 1991). The mouth is partially obstructed by a $900-$ $1100 \mathrm{~m}$ long unstable sand bar $4-6 \mathrm{~m}$ below the surface. The left bank is diked from the mouth to about $7 \mathrm{~km}$ upstream, while the right bank is diked as far as $9 \mathrm{~km}$ upstream. The bottom is sandy with several outcrops of granite and shale.

The quick-paced industrial and urban development of the region within the estuary's watershed threatens water quality and recreational and aesthetic value of this natural resource that has been, historically, of great importance to northern Portugal. Additionally, plans are being made to alter the configuration of the estuary's mouth with the construction of two 600$800 \mathrm{~m}$ long jetties. A study of the hydrodynamic behavior of the Douro estuary is fundamental for an effective management and an understanding of this waterway. This paper is a first contribution to this knowledge; it draws upon the only existing data to characterize the propagation of the tide into the estuary, describe the salinity structure under varying freshwater inflow regimes and offer estimates of water residence times.

\section{MATERIAL AND METHODS}

There are no data available from the Douro estuary prior to its damming in 1985 . The very first survey of this waterway is due to the Institute of Biomedical Sciences (ICBAS) of Porto University which carried out monthly two-dimensional surveys of the estuary from January to December of 1994 (Bordalo, 1997). Ten to twenty stations, between the mouth and the head of the estuary and located in the navigation

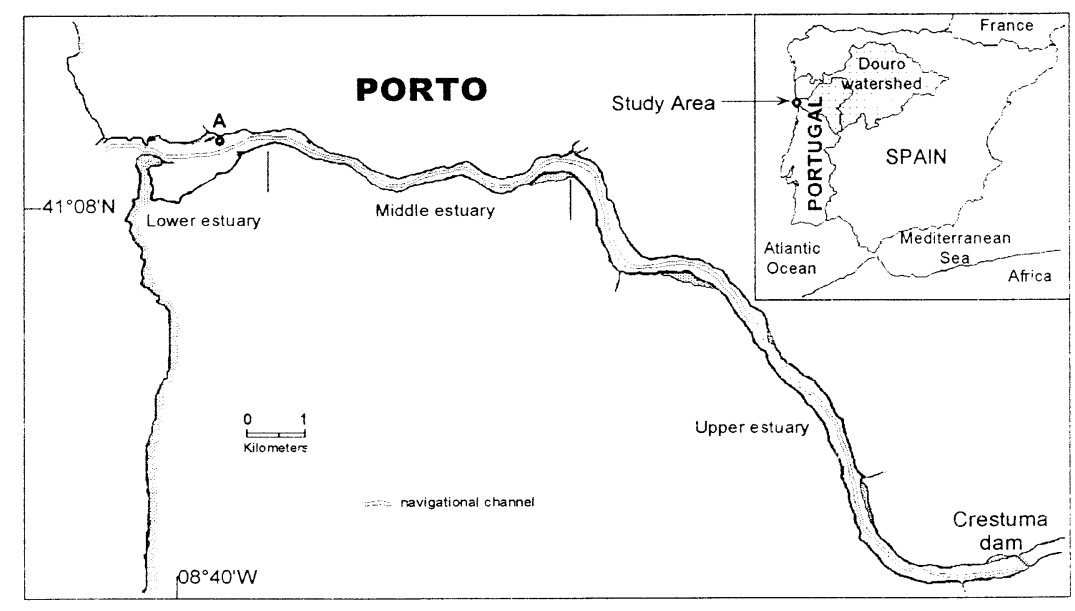

Figure 1. River Douro watershed and estuary with location of station A. Lower, middle and upper estuarine regions are indicated. 


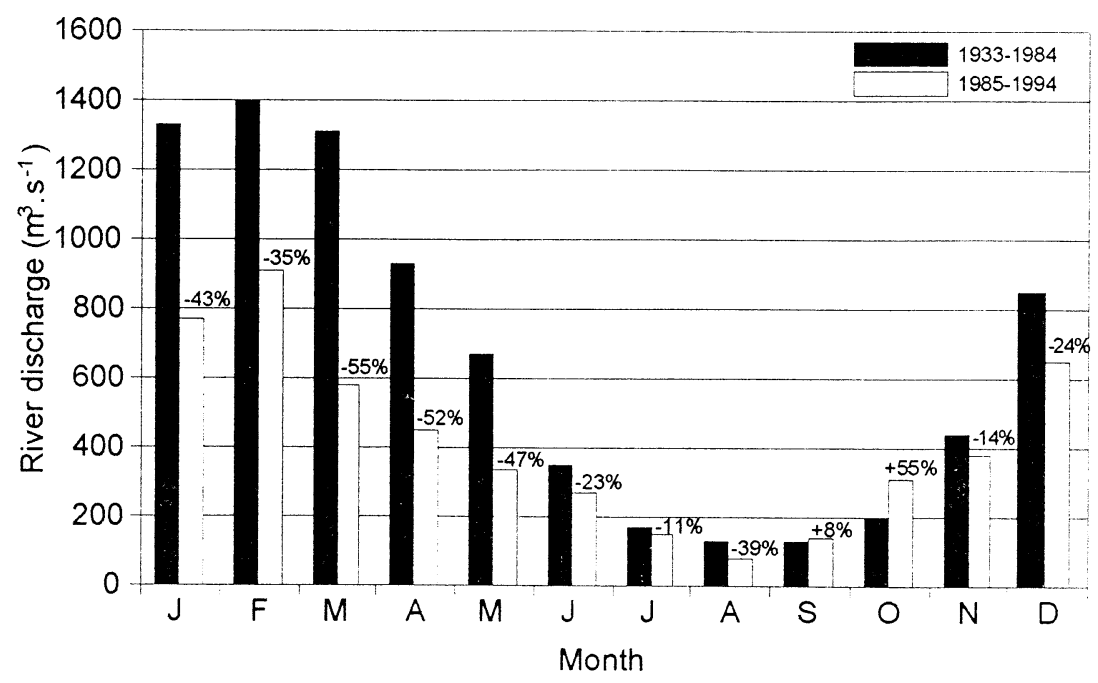

Figure 2. Average monthly flow into the Douro estuary for the periods 1933-1984 and 1985-1994. Percentages indicate an increase or decrease in the second period relative to the first.

channel, were occupied by a boat once per month at peak flood tide on a spring tide day. At each station salinity was measured with a YSI/Grant 3800 data logger equipped with a calibrated depth sensor every meter between the surface and $5 \mathrm{~m}$, then at $8 \mathrm{~m}, 10 \mathrm{~m}$ and $15 \mathrm{~m}$.

Also available were data obtained by the Hydrographic Institute of the Portuguese Navy in the lower estuary on 19 September 1994 at a time of spring tides (Instituto Hidrográfico, 1995). They consisted of measurements of current and salinity every $30 \mathrm{~min}$ over a period of $13.5 \mathrm{~h}(07: 30$ to $21: 00 \mathrm{~h})$ at station A (figure 1) in water $6 \mathrm{~m}$ deep. A direct reading Braystoke instrument was lowered to 3 depths at 0.5 $\mathrm{m}, 3 \mathrm{~m}$ and $5.5 \mathrm{~m}$. Water elevation was simultaneously recorded by a tide gauge from the National Tide Station Network, located near station A.

River flow entering the estuary was measured at the Crestuma dam by the Portuguese Electricity Authority; these daily averages are function of the amount discharged by the previous upstream dam as well as the regime of the Crestuma power station. The Douro River discharge suffered a decrease of about $42 \%$ since the last dam (Crestuma) was built in 1985. Figure 2 shows the monthly averaged runoff into the estuary before Crestuma (1933-1984) and after (1985-1994). The average yearly discharge plunged from $715 \mathrm{~m}^{3} \mathrm{~s}^{-1}$ to $421 \mathrm{~m}^{3} \mathrm{~s}^{-1}$, respectively, before and after 1985. The present regime is such that the largest freshwater runoff ( $48 \%$ of the yearly value) takes place from January to March, due to the release from the dams. Low summer flows are maintained in the estuary because of limited releases of water from the dams during the dry season. The average discharge into the Douro estuary in 1994, when this study was done, was $455 \mathrm{~m}^{3} \mathrm{~s}^{-1}$, consistent with the $421 \mathrm{~m}^{3} \mathrm{~s}^{-1}$ average for the decade.

The bathymetry used in this study was derived from data provided by the Douro Navigation Authority from surveys performed in 1993-1994.

\section{RESULTS AND DISCUSSION}

\subsection{Seasonal salinity structure}

The monthly salinity surveys carried out by the ICBAS provide a quasi-synoptic view of the estuary's structure. Figure 3 shows three longitudinal salinity contours from 11 March (a), 1 August (b) and 3 November (c), selected to illustrate the three principal regimes of the estuary.

In March (figure 3a), when the average of the three previous days' flow was $690 \mathrm{~m}^{3} \mathrm{~s}^{-1}$, the winter freshwater runoff was strong enough to keep the ocean 
water restricted to the estuary entrance, in the form of a short wedge, while immediately upstream partial mixing takes place. In this paper the salt wedge is defined as the mass of ocean water with salinity equal to or higher than 30. In the August survey (figure $3 b$ ), with a 3 day average flow of $77 \mathrm{~m}^{3} \mathrm{~s}^{-1}$, the salt wedge had penetrated about two thirds of the estuary; a very strong halocline had developed, allowing the fresh upper layer to extend out close to the estuary's entrance with little mixing. Tidal action did not destratify the estuary, in spite of the much reduced runoff. The November contours (figure 3c), corresponding to a 3-day average flow of $323 \mathrm{~m}^{3} \mathrm{~s}^{-1}$, revealed partial mixing in the middle reaches of the estuary, while the upper region was all fresh and again a salt wedge filled the initial portion of the estuary. At the peak of the winter outflow in January with a 3 day mean flow of 2800 $\mathrm{m}^{3} \mathrm{~s}^{-1}$, Douro freshwater occupied the entire estuary (not shown).

This is a highly dynamic estuary, driven principally by the amount of runoff allowed into it. High freshwater discharges push ocean water out of the estuary, even during spring flood tides. Low runoff allows a salt wedge to develop along the bottom and well into the estuary. Average flows, on the order of magnitude of the decade's average, allow a saltwater wedge to penetrate to some extent and permit modest mixing with river water in the middle reaches.

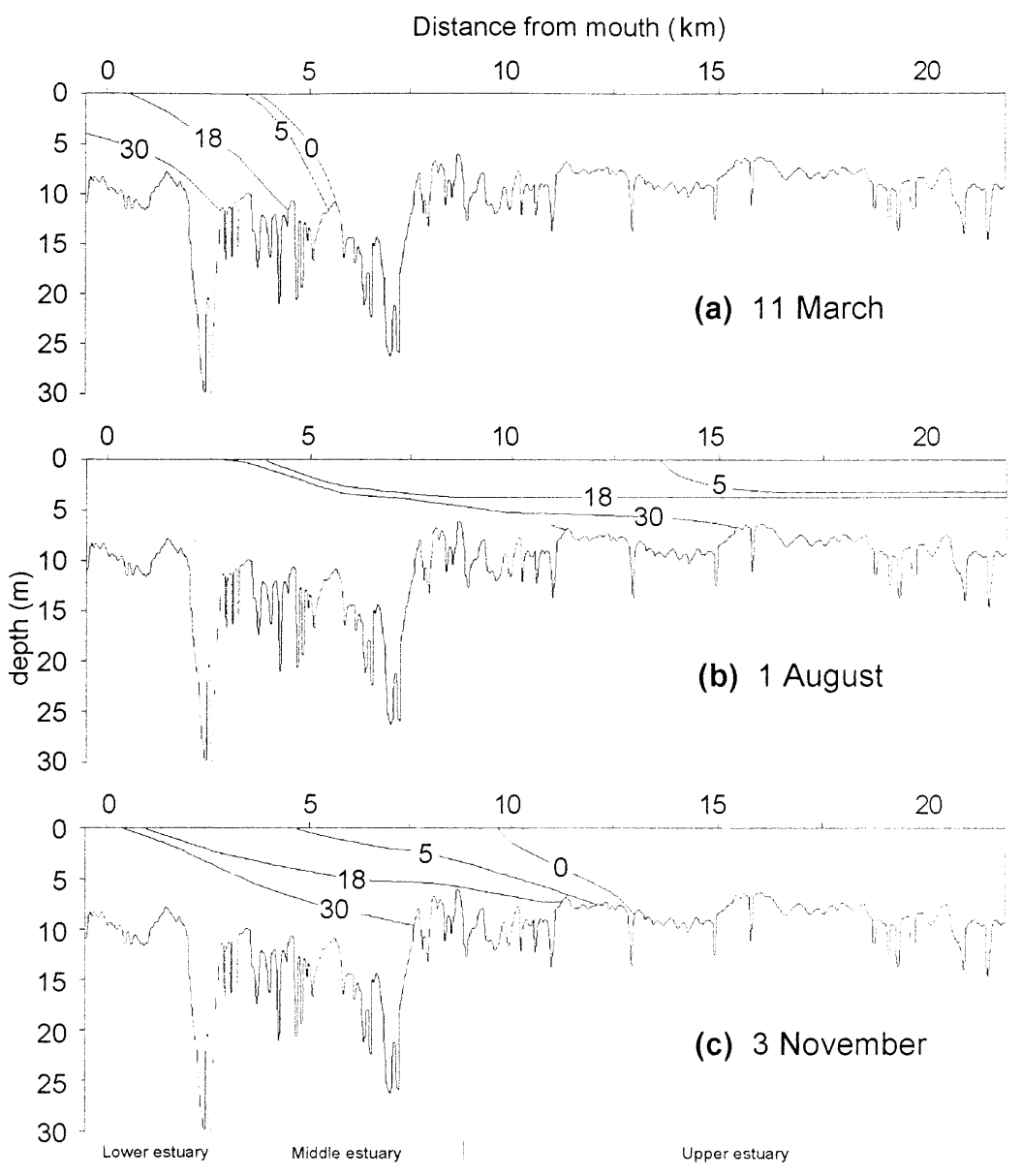

Figure 3. Longitudinal cross-sections of salinity in the Douro estuary during flood of spring tide under different discharge regimes. (a) 11 March 1994, river discharge $690 \mathrm{~m}^{3} \mathrm{~s}^{-1}$, (b) 1 August 1994, river discharge $77 \mathrm{~m}^{3} \mathrm{~s}^{-1}$, (c) 3 November 1994, river discharge $323 \mathrm{~m}^{3} \mathrm{~s}^{-1}$. Lower, middle and upper estuarine regions are indicated. 


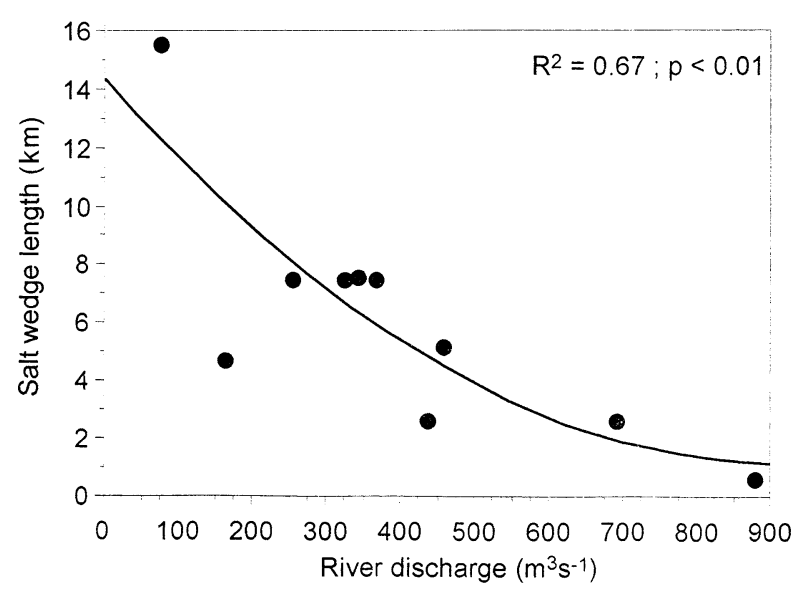

Figure 4. Polynomial regression of salt wedge length $(\mathrm{km}$ from mouth) versus river discharge $\left(\mathrm{m}^{3} \cdot \mathrm{s}^{-1}\right)$ in 1994. The discharges represent the average of the previous 3 days' flow.

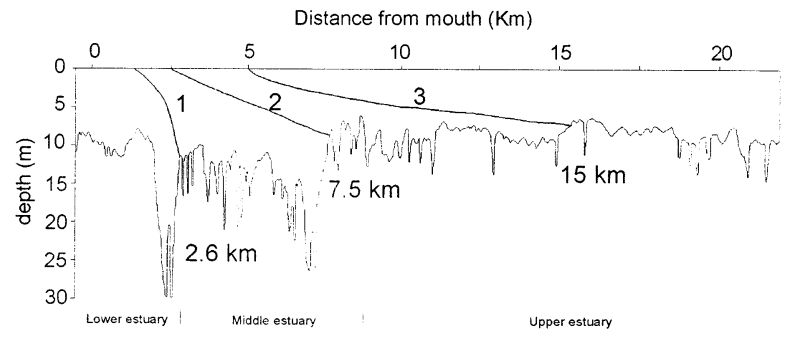

Figure 5. Predominant positions of the arrested salt wedge and respective distances $(\mathrm{km})$ to the mouth.

A polynomial regression between the extent of the salt wedge length (defined by the upstream position of the 30 isohaline) and river flow (figure 4) confirmed the relationship between runoff and estuarine regime. The weak regression $\left(\mathrm{R}^{2}=0.67, P<0.01\right)$ is explained by the bathymetry of the estuary, which arrests the salt wedge at three predominant positions, depicted in figure 5 and described below. River discharge higher than about $800 \mathrm{~m}^{3} \mathrm{~s}^{-1}$ does not allow the salt wedge to form and the estuary acts as a river. It is interesting to note that $800 \mathrm{~m}^{3} \mathrm{~s}^{-1}$ is the order of magnitude of the Douro river mean annual flow before 1985; as mentioned before, no hydrographic data from those years are available, but it is tempting to speculate whether before dam construction there might have been an estuary at all, or maybe only during the dry summer months or at least reduced to the first few kilometers.
On average the oceanic water intrusion was established from early spring (March) to early winter (December) and absent the rest of the year. When the salt intrusion begins the wedge gets arrested at position 1 (figure 5); this takes place for river discharges of less than about $700 \mathrm{~m}^{3} \mathrm{~s}^{-1}$. Position 1 corresponds to the deepest trough in the estuary, about $30 \mathrm{~m}$ of depth and $2.6 \mathrm{~km}$ from the estuary's mouth. For discharges of less than about $400 \mathrm{~m}^{3} \mathrm{~s}^{-1}$ the wedge advances to position 2, the next deep trough at $25 \mathrm{~m}$ of depth and $7.5 \mathrm{~km}$ from the mouth. Position 3 is reached when the river flow decreases to about 100 $\mathrm{m}^{3} \mathrm{~s}^{-1}$. At this maximum extent, the salt wedge reaches to within a mere $6 \mathrm{~km}$ of the head of the estuary at the Crestuma Dam. Position 1 was occupied in 1994 for about 2 months and position 3 for about 1 month in the summer. Position 2 was the most commonly taken, about 4 months in the year.

The available data did not allow the study of the dynamics of the salt wedge retreat and advance. The motion of the wedge may not be continuous and pools of salt water may be left behind on the bottom of the deepest sections of the estuary as the saline intrusion migrates downstream. These are some of the unresolved questions left for future investigation.

\subsection{Tidal characteristics}

The examination of the relationships between the tidal elevation, longitudinal current and salinity reveals some aspects of the behavior of the Douro estuary. Figure 6 shows hydrographic observations during one full tidal cycle collected by the Instituto Hidrográfico (1995) on 19 September 1994 (spring tide) at station A (figure 1), about $2 \mathrm{~km}$ from the mouth in water $6 \mathrm{~m}$ deep. It must be noted that at this time the river inflow was $165 \mathrm{~m}^{3} \mathrm{~s}^{-1}$ (much less than yearly average) and the salt wedge reached well upstream of this station during flood tide. Hence, these data illustrate the hydrodynamics inside the salt wedge, very close to the mouth of the estuary and at a time of low runoff.

The current velocity was almost exactly 3 hours out of phase with the water elevation; this is the signature of a standing wave situation. The current starts to flood at low water, peaks at mean tide level and ends at high water 6 hours later. Conversely, maximum 
ebb current velocity corresponds to the next mean tide level again. Salinity increases from slack before flood to slack before ebb and then decreases until the next slack before flood. At station A, close to the mouth, the tidal response is thus essentially that of a standing wave.

A standing wave in the Douro is not surprising. The tide is a shallow water wave which propagates into the estuary, where it is reflected at the head; resonance may ensue leading to the appearance of a standing wave whose wavelength $\mathrm{L}$

$\mathrm{L}=\mathrm{T}(\mathrm{g} \mathrm{D})^{1 / 2} / 4$
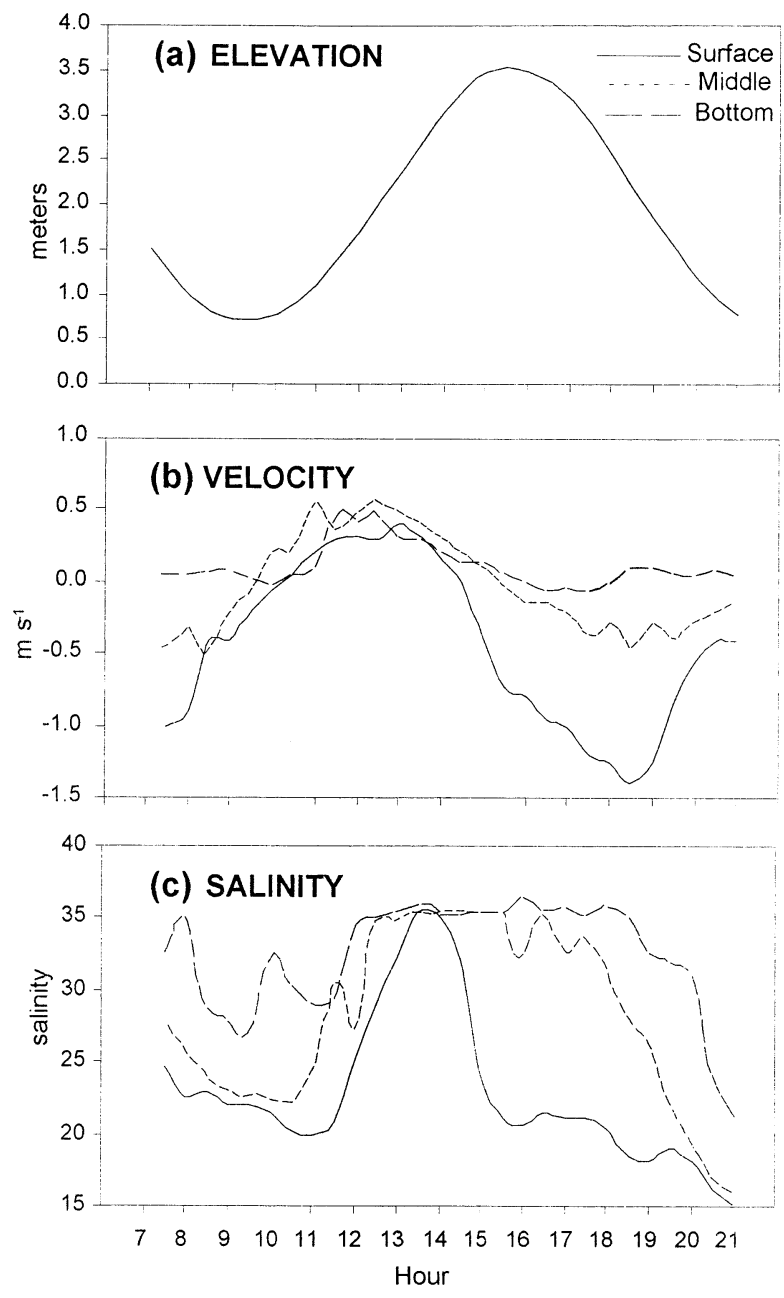

Figure 6. Tidal fluctuations at station A on 19 September 1994. (a) Tidal elevation (m). (b) Longitudinal velocity (positive up estuary) in $\mathrm{m} \mathrm{s}^{-1}$. (c) salinity. Depths: surface $(0.5 \mathrm{~m})$, mid-depth $(3 \mathrm{~m})$, bottom $(5.5 \mathrm{~m})$. is a function of the depth $\mathrm{D}$, period of the wave $\mathrm{T}$ and acceleration of gravity g (see e.g. (Pugh, 1987)). For the Douro estuary, with a mean depth of $7.8 \mathrm{~m}$ and considering the 12.4 hour period of the main semi-diurnal $\mathbf{M}_{2}$ tidal component, equation 1 yields a wavelength of $97.6 \mathrm{~km}$. Since the Douro estuary has a length of $21.6 \mathrm{~km}$, it is almost exactly a quarter wave resonator; it is as if the node of the standing wave were located at the mouth and only its final portion fit inside the estuary. The result is that the water level in the entire estuary goes up and down almost in unison during flood and ebb, and some degree of amplification of tidal range from mouth to head is expected. Supporting evidence for the mostly progressive tidal response of the estuary comes from an examination of the tide tables (Instituto Hidrográfico, 1993). They indicate that the water level directly in front of Crestuma Dam lags the tidal elevation at the mouth by about one hour; the absence of current velocity data at Crestuma precludes a determination of the proportion of progressive versus standing wave near the head. At Crestuma there is, however, no tidal amplification; actually the tidal range decreases by about $20 \mathrm{~cm}$ from the mouth to the head. Both the hour delay and the lack of tidal amplification are interpreted as resulting from frictional effects. As figure 1 shows, the middle and upper estuary constitute essentially a channel with monotonic depth and width; this lack of convergence allied to shallow water friction lends the Douro features of a synchronous estuary (Nichols and Biggs, 1985) resulting in relatively constant tidal range. In the light of these findings, we seek to answer the question: given that the Douro is a mesotidal estuary, why does it behave as a salt wedge most of the year, except during the winter?

Officer (1976), showed that the energy flow (power) transported across a transect by a standing wave is zero under frictionless conditions; more realistically, Pugh (1987) demonstrated that because the reflected wave has a smaller amplitude than the incident, due to frictional losses, the tide can be considered as the sum of a standing wave (no energy transported) and a progressive wave with a much reduced amplitude carrying a small amount of energy towards the head of the estuary. It was determined above that a small progressive component may be present in what is for the most part a standing wave response. This means, in the case of the middle and upper Douro estuary, 
that tidal forcing lacks enough power to mix the column even when a small river discharge is present. Hence, a highly stratified structure, particularly in the summer when runoff is at a minimum.

\subsection{Mixing}

Figure 6 also provides some insight into the mixing dynamics within the lower region of the salt wedge at a time of low fresh water discharge. Ebb velocities at the surface (figure $6 b$ ) were much larger than their flood counterparts, reaching about $1.5 \mathrm{~m} \mathrm{~s}^{-1}$ at peak ebb versus less than $0.5 \mathrm{~m} \mathrm{~s}^{-1}$ at peak flood. As the bottom is approached this ratio decreases and close to the river floor the current barely reverses from a predominant flooding condition throughout the tidal cycle. The duration of the ebb and flood was about equal throughout the column, except at the surface where the ebb started one hour earlier. Vertical shear was minimal during flood, with maximum value on the order of $0.05 \mathrm{~s}^{-1}$; however, during ebb, it attained larger magnitudes on the order of $0.3 \mathrm{~s}^{-1}$ at peak ebb. This is a clear case of tidal straining, as figure $6 c$ elucidates, with fresher water on the ebb cycle moving faster than the salty bottom water slowed down by friction, leading to an abrupt decrease of salinity at the surface relative to that experienced by bottom waters. During flood, on the contrary, stratification is reduced by the straining and mixing is more intense near the bottom.

The shear vector pointed always downstream, thus explaining the increased shear during the ebb cycle. This is consistent with the balance of forces during the tidal cycle. Throughout the flood the residual current (due to density) in the surface waters was downstream, while in the bottom waters it was upstream. The tidal current opposes the residual in the upper layers but reinforces it in the lower layers; however, bottom friction is opposed to it. The contrary is true during ebb: in the upper layers tidal forcing and residual current reinforce each other, whereas in the lower layers tidal forcing is opposed by both residual flow and bottom friction. These findings are similar to those of Geyer and Farmer (1989) reporting on tidal variability in the middle reaches of the macrotidal salt wedge Fraser estuary.
Salinity fluctuated by about 20 during the complete tidal cycle (figure 6c). Salinity rose sharply throughout the column with the onset of flood tide at $10 \mathrm{~h}$; straining enhanced mixing closer to the bottom, so that the lower half of the column was mixed by about $12 \mathrm{~h} \mathrm{30}$. It took another hour for the surface waters to destratify and for a completely mixed column to be established. At this time the stratification was gone and the whole column contained salt water. This situation remained until about $14 \mathrm{~h}$. Then, as soon as ebb started around $14 \mathrm{~h} 30$, tidal straining quickly stratified the upper layer in two hours; the rate of stratification then decreased and it took another five hours for the surface waters to reach minimum salinity at $21 \mathrm{~h}$, some 2.5 hours after peak ebb at $21 \mathrm{~h}$. The bottom waters kept flooding until about $15 \mathrm{~h} 30$. Vertical shear between the fresher water flowing out and the slowly moving middle waters built up and around $17 \mathrm{~h} 30$ was strong enough to finally generate vertical mixing. The mid-depth salinity began a steady decrease until it reached the same value as the surface layers at $20 \mathrm{~h}$, one hour and a half after maximum ebb. In the meantime the vertical shear decreased, never having been intense enough to completely mix the column, allowing the bottom waters to maintain some degree of stratification. This situation was maintained throughout the remaining ebb cycle, until the onset of the next flood, when again the incoming oceanic water will eventually homogenize the column from top to bottom.

Hence, in the lower estuary undergoing salt wedge conditions, it is apparent that tidal straining prevents the column from mixing thoroughly during the ebb period. During flood, however, the column destratifies and eventually becomes thoroughly mixed with the inflow of pure ocean water.

Further research is needed to investigate the role of shear stress in the upper reaches of the estuary, particularly in the region adjacent to the tip of the salt wedge, during different runoff regimes.

\subsection{Flushing times}

An attempt was made to quantify the volume of water exchanged between main sections of the estuary under different regimes and to estimate the corresponding flushing times. The flushing time (or resi- 


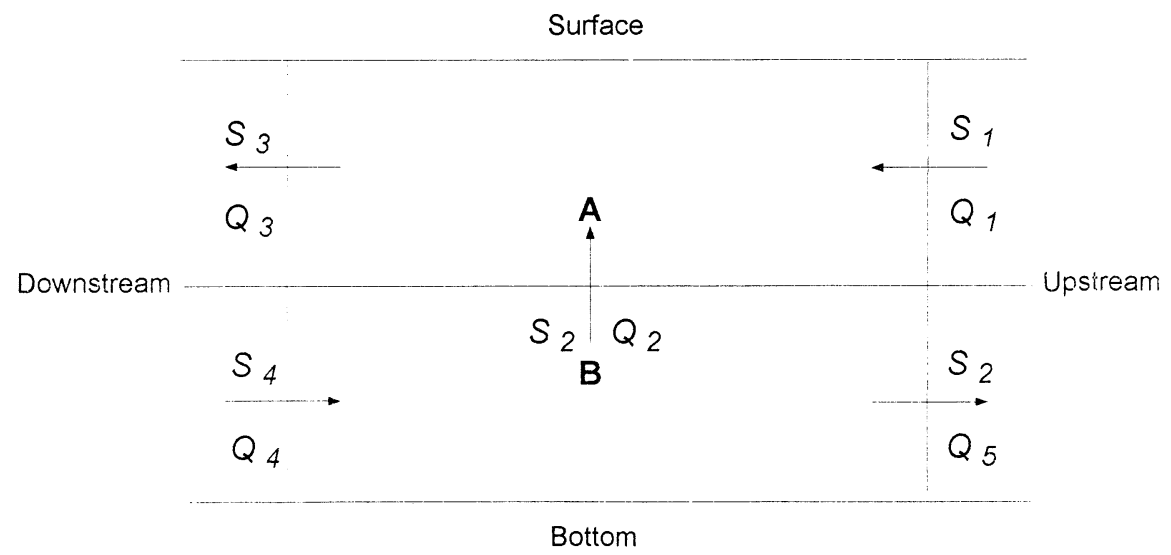

Figure 7. Schematic for two-layered box model.

dence time) has been defined as the time it takes to replace the amount of fresh water in an estuary at the rate of fresh water inflow from the river (Dyer, 1997). Flushing time can thus be understood as the duration of the permanence of a parcel of water in the estuary before it is delivered to the ocean.

Given that in an estuary salty oceanic water and river fresh water mix to some degree, in its simplest form the flushing time $\mathrm{T}$ is given by:

$\mathrm{T}=\mathrm{V} / \mathrm{R}$,

where $\mathrm{V}$ is the low tide volume of the estuary and $\mathrm{R}$ is the river discharge. Equation 1 implies thorough mixing of the saline water entering the estuary during flood tide with fresh water from land drainage. This assumption is not realistic in the Douro River, since as demonstrated above, the column is stratified some 9 months in the year. Instead, a modified water and salt budget model was implemented, based on Knudsen's hydrographic theorem (Dyer, 1997).

The model maintains a two-layered structure throughout the estuary, allowing for a small amount of mixing as determined from the proportion of existing salt. We assume the waterway divided into a small number of boxes, each made up of two homogeneous layers: a more saline bottom and a less saline top layer. The innermost box corresponds to the partially mixed portion of the estuary, adjacent to the tip of the wedge; it only allows fresh water inflow in the top layer while no salt water is exported upstream from the bottom layer. Vertical advection is allowed for continuity, representing entrainment of bottom water.
Figure 7 illustrates the scheme utilized for this box model. $\mathrm{Q}_{1}$ represents the flow rate $\left(\mathrm{m}^{3} \mathrm{~s}^{-1}\right)$ of water with salinity $S_{1}$ into the top layer through the upstream cross-section, while $\mathrm{Q}_{3}$ is the flow rate out of water with salinity $S_{3}$. Similarly, $Q_{4}$ is the flow rate of water with salinity $S_{4}$ into the bottom layer through the downstream cross-section, while $\mathrm{Q}_{5}$ is the flow rate out with salinity $S_{2}$. Salinities $S_{3}$ and $S_{4}$ were obtained by averaging the salinity data from the ICBAS 1994 survey in each section. Assuming conservation of water and salt we obtain:

$\mathrm{Q}_{3}\left\{1-\left(\mathrm{S}_{3} / \mathrm{S}_{4}\right)\right\}=\mathrm{Q}_{1}\left\{1-\left(\mathrm{S}_{1} / \mathrm{S}_{2}\right)\right\}$

and

$\mathrm{Q}_{4}\left\{\left(\mathrm{~S}_{4} / \mathrm{S}_{3}\right)-1\right\}=\mathrm{Q}_{5}\left\{\left(\mathrm{~S}_{2} / \mathrm{S}_{1}\right)-1\right\}$

The estimates start at the most upstream box, corresponding to the partially mixed portion of the estuary adjacent to the tip of the wedge; in this box $Q_{1}$ is the river discharge, $\mathrm{S}_{1}=0, \mathrm{Q}_{5}=0$ and $\mathrm{Q}_{3}=\mathrm{Q}_{1}+\mathrm{Q}_{4}$. The calculations are repeated for the adjacent boxes in succession towards the mouth.

The flushing times $T_{A}$ for section $A$ and $T_{B}$ for section $\mathrm{B}$ are given by:

$\mathrm{T}_{\mathrm{A}}=\mathrm{V}_{\mathrm{A}} / \mathrm{Q}_{3} \mathrm{~T}_{\mathrm{B}}=\mathrm{V}_{\mathrm{B}} / \mathrm{Q}_{4}$

where $V_{A}$ and $V_{B}$ are the volumes of sections $A$ and $B$, respectively.

The estimates were carried out for the three principal regimes of the estuary in March, August and November. The results are presented in table I. Not surprisingly, residence times increase with decreasing fresh 
Table I. Flushing times, in hours, in the Douro estuary. Box length in kilometers from river mouth. $\mathrm{R}$ is the river discharge in $\mathrm{m}^{3} \mathrm{~s}^{-1}$.

\begin{tabular}{|c|c|c|c|c|c|c|c|c|c|}
\hline & \multicolumn{3}{|l|}{$\begin{array}{l}\text { March } \\
\mathrm{R}=690\end{array}$} & \multicolumn{3}{|l|}{$\begin{array}{l}\text { August } \\
\mathrm{R}=77\end{array}$} & \multicolumn{3}{|l|}{$\begin{array}{l}\text { November } \\
\mathrm{R}=323\end{array}$} \\
\hline & \multirow[t]{2}{*}{ Box length } & \multicolumn{2}{|l|}{ Layer } & \multirow[t]{2}{*}{ Box length } & \multicolumn{2}{|l|}{ Layer } & \multirow[t]{2}{*}{ Box length } & \multicolumn{2}{|l|}{ Layer } \\
\hline & & Upper & Lower & & Upper & Lower & & Upper & Lower \\
\hline & $0.0-2.0$ & 0.6 & 1.8 & $0.0-3.3$ & 0.2 & 0.4 & $0.0-2.0$ & 0.1 & 0.5 \\
\hline & $2.0-5.2$ & 0.9 & 4.7 & $3.3-6.8$ & 2.8 & 84.9 & $2.0-6.8$ & 2.4 & 14.1 \\
\hline & & & & $6.8-14.2$ & 22.5 & 154.2 & $6.8-14.2$ & 5.8 & 68.6 \\
\hline & & & & $14.2-21.6$ & 16.0 & 115.5 & & & \\
\hline \multirow[t]{2}{*}{ Flushing times } & Layer & 1.5 & 6.5 & & 41.5 & 355.0 & & 8.3 & 83.2 \\
\hline & Total estuary & $\begin{array}{l}8.0 \\
\text { (0.3 days) }\end{array}$ & & & $\begin{array}{l}396.5 \\
\text { (16.5 days) }\end{array}$ & & & $\begin{array}{l}91.5 \\
\text { ( } 3.8 \text { days) }\end{array}$ & \\
\hline
\end{tabular}

water inflow. A Spring situation, as in March, has the estuary flush completely in less than one tidal cycle. The fall scenario, with fresh water discharge on the order of magnitude of the average yearly value, results in the estuary taking between 7 and 8 tidal cycles to flush. In the Summer, with inflow at a minimum, a complete flushing of the estuary is accomplished in about 32 tidal cycles. Taking the November fresh water discharge as a reference, we conclude that a two-fold increase in discharge reduces the estuary's residence time by a factor of roughly 10 ; fresh water reduction by a factor of 4 results in a residence time increase by a factor of 4 .

\section{CONCLUSIONS}

The Douro estuary features a salt wedge whose behavior is controlled mostly by the river inflow. During low river discharge periods (less than $800 \mathrm{~m}^{3} \mathrm{~s}^{-1}$ ) the salt wedge is permanently installed; it is entirely pushed out of the estuary when the discharge is higher than that. This is consistent with Ibañez et al. (1997) who proposed a 'first type' of highly stratified microtidal estuary: a salt wedge during low runoff, a river during high inflow. What is different about the Douro is that it is subjected to a mesotidal regime, not a microtidal one. It might be expected that given the magnitude of the tidal range (as large as $2.8 \mathrm{~m}$ at spring tides) and a mean freshwater discharge of 421 $\mathrm{m}^{3} \mathrm{~s}^{-1}$, the tide would be energetic enough to prevent strong stratification, generating instead partially mixed conditions. The Douro's remarkable departure from this scenario is related to the nature of the standing wave features of the tidal wave inside the estuary. The analysis of data in the lower part of the estuary, inside the salt wedge and during low river discharge conditions, indicates that tidal straining plays a critical role in the dynamics of vertical mixing of the column, such that during ebb stratification is preserved, while flood succeeds in mixing the column thoroughly.

The consequences of this behavior are manifold and may determine many features of this estuarine system, from water quality to sedimentation and the ecological environment. Further field studies are needed to collect data from this entire estuary under different runoff regimes. These will support research directed to an understanding of the details of the salt wedge advance and retreat in response to tidal dynamics (flood and ebb, fortnightly), freshwater runoff and possibly meteorological forcing.

\section{Acknowledgements}

The authors wish to thank the Douro Harbormaster (Portuguese Navy) for supplying the survey vessels and their crews. MV thanks the US Naval Academy for making his sabbatical leave possible; he also gratefully acknowledges the support of the Hydrographic Institute (Portuguese Navy) during his sabbatical work at that institution and for making accessible the September 1994 data, as well as two anonymous reviewers for their valuable comments. This research was partially funded by JNICT/PEAMB 231/93 and is contribution no. 3 . 


\section{REFERENCES}

Bordalo, A.A., 1991. Ecology of river Douro estuary. Spatial and temporal dynamics of the microbial compartment. Ph.D. dissertation, Porto Univ. Porto, Portugal (in Portuguese).

Bordalo, A.A., 1997. Towards the management of Douro River estuary. Technical Report JNICT/PEAMB 231/93. Instituto de Ciências Biomédicas Abel Salazar, Porto Univ. Porto, Portugal (in Portuguese).

Davies, J.H., 1964. A morphogenetic approach to world shorelines. J. Geomorph. 8, 127-142.

Dyer, K.R., 1997. Estuaries: A Physical Introduction. John Wiley, Avon.

Geyer, W.R., Farmer, D.M., 1989. Tide-induced variation of the dynamics of a salt wedge estuary. J. Phys. Oceanogr. 19, $1060-1072$.
Ibañez, C., Pont, D., Prat, N., 1997. Characterization of the Ebre and Rhone estuaries: a basis for defining and classifying saltwedge estuaries. Limn. Oceanogr. 42, 89-101.

Instituto Hidrográfico, 1993. Tide tables 1994, Vol. I. Ministério da Defesa Nacional, Marinha, Lisboa, Portugal (in Portuguese).

Instituto Hidrográfico, 1995. Hydromorphological survey for the study of the Douro mouth.Techn. Rep. REL.TF.OF.02/95, Instituto Hidrográfico, Marinha, Lisboa, Portugal (in Portuguese).

Nichols, M.M., Biggs, R.B., 1985. In: Davis, R.A. (Eds.), Estuaries Coast. Sediment. Environ. Springer-Verlag, New York, pp. 77-186.

Officer, C.B., 1976. Physical Oceanography of Estuaries. John Wiley, New York.

Pugh, D.T., 1987. Tides, Surges and Mean Sea Level. John Wiley, Avon. 